\title{
Efforts to Increase Economic Learning Motivation Online through Improving Learning Facilities, Teacher Creativity and Social Support during the COVID-19 Pandemic
}

\author{
Endah Ratnawati ${ }^{1}$, Subagyo ${ }^{2}$, Sugiono ${ }^{3}$ \\ ${ }^{1,2,3}$ Masters of Economic Education, University of Nusantara PGRI Kediri, Indonesia \\ Corresponding Author: Endah Ratnawati
}

DOI: https://doi.org/10.52403/ijrr.20220247

\begin{abstract}
This study aims to determine the effect of learning facilities, teacher creativity and social support on motivation to learn economics either partially or simultaneously during online learning in the midst of the Covid-19 pandemic. This study used a quantitative approach to the type of causality research. The research subjects were students of class X of Islamic Senior High School 1 Nganjuk of the 2020/2021 academic year, totaling 270 students. A sample of 135 students was obtained from the Isaac and Michael formula. Sample selection used was proportional random sampling technique. Data were analyzed using descriptive analysis and multiple linear regressions with the help of SPSS 25 for windows. The results showed that learning facilities and teacher creativity partially had a significant positive effect on economic learning motivation, while social support partially had no effect on economic learning motivation because with online learning students lost social support from friends as a source of social support other than teachers and parents. Learning facilities, teacher creativity and social support simultaneously had a significant positive effect on motivation to learn economics. And other factors that influence learning motivation outside the model include interest in the material, ideals or aspirations, student conditions, teacher personality and environmental conditions where students live.
\end{abstract}

Keywords: Learning Motivation, Learning Facilities, Teacher Creativity, Social Support

\section{INTRODUCTION}

The spread of Corona Virus Disease 2019 (Covid-19) was so fast and widespread that physical distancing and social distancing policies have emerged as an effort to prevent Covid-19, which has resulted in the social condition of the community becoming weak and slowing down drastically (Kresna \& Ahyar, 2020). The impact in the education sector was the emergence of Policy No. 4 of 2020 concerning the implementation of education during the spread of COVID-19, all educational institutions had to keep their distance and the delivery of learning materials was conducted from homes online (Kemendikbud, 2020). With the use of online-based applications, it was expected to produce students who are knowledgeable, able to develop themselves in a sustainable manner and increase productivity (Zaharah et al., 2020).

In facts, online learning experiences several obstacles, according to research by Agustina \& Kurniawan (2020) common obstacles like inadequate internet facilities, less understandable learning process, uninteresting learning material and too many tasks so that decrease students learning motivation. On the other hand, teachers who were capable to create a favorable classroom atmosphere turned into difficulties in controlling the learning 
climate which resulted in students' learning motivation to decrease and even affect learning outcomes (Sari \& Rusmin, 2018). In line with this, Purwanto et al., (2020) stated that online learning led to boredom, lack of efficiency, lack of concentration and difficult in understanding, asking questions and discussing the material being studied. Likewise, Emda \& Amna (2018) found that the learning climate created by online learning has affected the decline in students' learning motivation. For this reason, according to Meyer \& Turner (2006), efforts were needed to create a positive and consistent learning climate in the classroom by integrating emotions, motivation and cognition as the basis for relationships and interactions between teachers and students. Furthermore, Cahyani et al. (2020) stated that the learning motivation of students who took part in online learning in the midst of the Covid-19 pandemic situation had decreased; only a few students participated and were active in learning.

Islamic senior high school 1 Nganjuk, since the beginning of the Covid19 pandemic, has implemented an online learning system. From the results of the initial survey, it was known that during online learning, the learning motivation of class XI students was less than optimal. This could be seen from the fewer students who participate, poor study habits, lack of learning facilities, teachers who are less able to innovate and be creative in the learning process, a less supportive social environment, and lack of awareness of students in an effort to improve achievement so that motivation learning goes down which in the end the score of economic learning was less than satisfactory.

Seeing the facts above, the authors desire to analyze efforts to increase motivation to learn economics through improving learning facilities, teacher creativity and social support for students of class XI of Islamic senior high school 1 Nganjuk. The purpose of this research was to determine and analyze the influence of learning facilities, teacher creativity and social support either partially or simultaneously on the motivation to learn economics.

\section{LITERATURE REVIEW Motivation to Study}

According to Machr and Meyer (in Brophy, 2010) motivation is defined as a theoretical construct used to explain the initiation, direction, intensity, persistence, and quality of goal-directed behavior. Meanwhile, Uno (2011) argues that learning motivation is internal and external encouragement for students who are learning to make changes in behavior which are indicated by the desire and interest, encouragement and needs, hopes and ideals as well as appreciation and respect. As an effort to increase learning motivation in online learning, according to Sukiyasa \& Sukoco (2013) are: 1) improving the quality of teachers to improve the quality of learning; 2) choosing the right learning method; 3) maximizing learning facilities; 4) taking advantage of the use of learning media; and 5) evaluating learning.

\section{Learning Facilities}

Learning facilities according to Sardiman (2007) are a means to facilitate and expedite the learning outcomes achieved. Learning facilities include all the facilities needed in the learning process, both movable and immovable so that the achievement of learning objectives can run smoothly, effectively and efficiently so that students can achieve optimal results (Cynthia et al., 2015). The effect of learning facilities on learning motivation, according to Arsyad (2009) is that the benefits of learning facilities are to increase and excite students' attention so that it creates learning motivation.

\section{Teacher Creativity}

Slameto (2010) defines teacher creativity as the ability of teachers to develop new ideas and ways of educating, teaching, guiding, directing, training, assessing and evaluating students. 
Meanwhile, Noor Rochman Hadjam (in Talajan, 2012) that teacher creativity can be directed at two components, namely creativity in classroom management and teacher creativity in the use of learning media. Teacher creativity in classroom management, in the form of the ability to plan activities in the classroom will create a conducive classroom climate can be created consistently for the learning process. Furthermore, the creativity of teachers in the use of learning media is how teachers are able to optimize the functions of learning media such as: 1) helping students understand the abstract concepts being taught; 2) increase the motivation of students in learning; 3) reduce the occurrence of misunderstandings; and 4) motivate to develop knowledge.

\section{Social Support}

Social support, according to Sarafino (1997) is a dynamic process, which is a form of existence, willingness and concern from reliable people such as family or friends to appreciate and love individuals who influence changes in the individual's behavior. According to him, there are five components of social support as the followings: 1) Emotional support, which includes expressions of empathy, care and concern for individuals; 2) Appreciation support, in the form of positive appreciation for individuals, encouragement or approval of ideas; 3) Instrumental support, in the form of direct assistance such as money or material, time and energy through actions that can help individuals; 4) Informative support, including giving advice, instructions, suggestions or feedback and 5) Network support, it is the feeling of being part of a group member. (8)

Cohen and Downey (in Smet, 1994) stated that the social support received by individuals can vary depending on the quantity and quality of support, the source of support and the type of support. According to learning motivation, Rosa's research results (2020) that there is a significant influence between social support on students' learning motivation. Likewise, research results from Permatasari et al. (2021) found that social support from peers, family and teachers has a significant effect on academic resilience during online learning, and the most dominant contribution is social support from family.

\section{MATERIALS \& METHODS}

This research used a quantitative approach and was a causality study. The population in this study was 270 students of class XI of Nganjuk Islamic School. The sample found was 135 students obtained by using the Issac and Michael formula (Sugiyono, 2011). The sampling technique used was proportional random sampling. Collecting data used were a questionnaire via Google form, documentation and interviews. The research instrument used was a Likert scale which includes a scale of learning motivation, learning facilities, teacher creativity and social support, each of which has been tested for valid and reliable items. The data analysis technique used descriptive analysis and multiple linear regressions with the help of SPSS 25 for windows.

\section{RESULT}

Before conducting multiple linear regression analysis, a prerequisite analysis test was conducted in order to obtain the BLUE (Best Linear Unbiased Estimator) estimator. The test results shown that the tested data was normally distributed, each independent variable had a linear relationship to the dependent variable, there was no multicollinearity and there was no heteroscedasticity so that the analysis prerequisite test was met. (11)

Furthermore, testing with multiple linear regression analysis obtained the following results:

Table 1: Results of Multiple Linear Regression Analysis

\begin{tabular}{|l|l|l|l|}
\hline Variables & $\begin{array}{l}\text { Regression } \\
\text { Coefficient }\end{array}$ & $\mathbf{t}$ & Sig. \\
\hline Learning Facilities (X1) & 0,424 & 4,462 & 0,000 \\
\hline Teacher Creativity (X2) & 0,435 & 5,666 & 0,000 \\
\hline Social Support (X3) & 0,036 & 0,640 & 0,523 \\
\hline constant & 6,166 & & \\
\hline $\mathrm{R}^{2}=0,485$ & $\mathrm{~F}_{\text {counted }}=41,066$ \\
\hline Adjusted $\mathrm{R}^{2}=0,473$ & Sig. $=0,000$ \\
\hline \multicolumn{4}{|l|}{ Source: primary data processed, 2021}
\end{tabular}


From Table 1 above, the regression line equation formed was $\mathrm{Y}=6.166+$ $0.424 \mathrm{X} 1+0.435 \mathrm{X} 2+0.036 \mathrm{X} 3+$. The constant of 6.166 meant that if $\mathrm{X} 1, \mathrm{X} 2$ and $\mathrm{X} 3$ have no effect on $\mathrm{Y}$ then the magnitude of $\mathrm{Y}$ was 6.166. The $\mathrm{X} 1$ regression coefficient was (+) 0.424 , meaning that the effect of learning facilities on learning motivation was positive. Every $1 \%$ increase in learning facilities would contribute to an increase in learning motivation by $0.424 \%$. The regression coefficient of $\mathrm{X} 2$ was $(+)$ 0.435 , which meant that the influence of teacher creativity on learning motivation was positive. Every time there was an increase in teacher creativity by $1 \%$, it would contribute to an increase in learning motivation by $0.435 \%$. The $\mathrm{X} 3$ regression coefficient of 0.03 meant that the effect of social support on learning motivation was very small (not significant). The coefficient of determination (adjusted $\mathrm{R}$ square) was 0.473 , indicating that the variance in economic learning motivation could be explained by learning facilities, teacher creativity, and support by $47.3 \%$ through the regression model while the remaining $52.7 \%$ was explained by other variables that were not taken into account in the model.

Based on the hypothesis test, in Table 1 above for the learning facility variable (X1), the $\mathrm{t}$ counted was $4.462>\mathrm{t}$ table 1.918 and the value of Sig. $0.000<0.05$ then Alternative Hypothesis 1 (H1) was accepted, meaning that learning facilities partially had a significant effect on motivation to learn economics. The teacher's creativity variable (X2) obtained $t$ counted of $5.666>\mathrm{t}$ table of 1.918 and the value of Sig. $0.000<0.05$ then Alternative Hypothesis 2 (H2) was accepted, meaning that teacher creativity partially has a significant effect on economic learning motivation. The social support variable (X3) obtained $t$ count of $0.640<\mathrm{t}$ table of 1.918 and the value of Sig. $0.523>0.05$ then Alternative Hypothesis 3 (H3) was rejected, meaning that partial social support had no significant effect on learning motivation. Furthermore, the calculated $F$ value is $41.066>F_{\text {table }} 2.673$ and the Sig value. $0.000<0.05$ then Alternative Hypothesis $4(\mathrm{H} 4)$ was accepted, meaning that learning facilities, teacher creativity and social support simultaneously have a significant effect on motivation to learn economics.

\section{DISCUSSION}

\section{The Effect of Learning Facilities on Economic Learning Motivation}

There was a significant influence of learning facilities on the motivation to study economics, as shown from the results of interviews with the counseling coordinator that the learning motivation of students tent to decline at the beginning of the pandemic, mainly due to quota limitations. With the provision of free quota assistance from the Ministry of Religion, starter cards from sponsors as well as computer or laptop facilities along with internet (Wi-fi) provided by school for students who did not have a quota, even those who did not have Smartphone, in fact they were able to overcome obstacles in online learning so that affect the learning motivation of students for the better. In line with the opinion of Arsyad (2009) that the benefits of learning facilities could increase and excite the attention of students, causing learning motivation. Meanwhile, the results of Jannah \& Sontani's research (2018) shown that learning facilities and infrastructure have a strong direct relationship with students' learning motivation. Likewise, Lagili et.al. (2019) that the most influential factor on learning motivation was physiological needs (learning facilities).

\section{The Influence of Teacher Creativity on Learning Motivation}

There was a significant influence of teacher creativity on motivation to learn economics, as evidenced by the results of the questionnaire with the highest score on the items "Teachers involve students in economic learning" and "I participate in online learning", meant that economics teachers had been able to carry out active 
learning, and able to involve students in the online learning process. The methods used by teachers also vary, such as e-learning, Google classroom, YouTube, Edmodo, Canva and so on. Mastery of these applications was obtained from the results of training, webinars, Subject Teacher Forum and so on. Kasmaienezhadfard et al. (2015) research that creativity and creative problem solving were identified as the main factors in achieving educational goals, through the creativity of teachers in teaching being able to create active and creative learning. Meanwhile, according to Kettler et al. (2018) that teachers' perceptions of creativity in the classroom were different. Teachers who had high creativity know more about the characteristics of students so that with their creativity, what were the learning objectives could be achieved as targeted. The same thing was also expressed by Sari \& Rusmin (2018) that teachers were required to be able to design learning media as innovations by utilizing online media, further increasing their creativity in the process of teaching and learning activities so that the classroom climate was controlled, because the classroom climate had a significant influence on learning motivation.

\section{The Effect of Social Support on Learning Motivation}

Partial social support gave no significant effect, but together with the variables of learning facilities and teacher creativity had a significant effect on motivation to learn economics, it meant that the existence of social support in an effort to increase motivation to learn economics could not be done without the control of learning facilities and creativity. Teacher, for example, if there was high social support from parents (such as frequent advice, attention, appreciation, comfort) if it was not supported by the provision of adequate learning facilities such as internet quotas, the increase in social support would have less effect on motivation to study economics. According to the author, there was no significant effect of social support on economic learning motivation because on the one hand there was an imbalance in the type of support, where parents were more likely to increase the fulfillment of emotional, rewarding and informative support but provide less instrumental support to their children so that the effect on learning motivation was less optimal. However, parents also could not be blamed because providing more instrumental support requires additional funds, while the majority of students come from lowermiddle families, especially during the COVID-19 pandemic, the global economic condition was declining. And on the other hand there was a loss of one source of social support, like friends as a result of online learning. This was proven from the results of the questionnaire, the items "Parents help me when there is a problem" and "Parents give positive comments to me" got the highest score. While the items "Friends ask me when I'm feeling down", "Friends cheer me up when I'm sad" and "Friends remind me every time I have an economic task" got the lowest scores, meaning that there has been a decline and even loss of the role of social support from friends. Meanwhile, social support from parents became more dominant. In line with Tan's research (2020) that students lose motivation and learning performance during online learning due to the lack of facilities and infrastructure that support learning and the lack of social support from lecturers and peers.

\section{CONCLUSION}

From the results of the study, it can be concluded that during online learning in the Covid-19 pandemic, learning facilities and teacher creativity partially have a significant effect on increasing economic learning motivation, while social support has no significant effect because students have lost the role of social support from friends so that it is less influential on the motivation of study economics. And together learning facilities, teacher creativity and social support have a 
Endah Ratnawati et.al. Efforts to increase economic learning motivation online through improving learning facilities, teacher creativity and social support during the COVID-19 pandemic.

significant positive effect on motivation to learn economics.

\section{SUGGESTIONS FOR FURTHER RESEARCH DEVELOPMENT}

The author realizes that the results of this study are not absolutely accurate. There are many other efforts that can increase learning motivation. Each student is unique, each of which has different characteristics, the higher the teacher's ability to understand the characteristics of students, the easier it will be with creativity to achieve learning goals. For this reason, teacher creativity needs to be developed further.

\section{Acknowledgement: None}

\section{Conflict of Interest: None}

\section{Source of Funding: None}

\section{REFERENCES}

1. Agustina, M. T., \& Kurniawan, D. A. (2020). Motivasi Belajar Mahasiswa di Masa Pandemi Covid-19. Jurnal Psikologi Perseptual, $5(2)$ 120 https://doi.org/10.24176/perseptual.v5i2.516 8

2. Arsyad. (2009). Psikologi Kependidikan. Bandung: PT Remaja Rosdakarya.

3. Brophy, J. (2010). Motivating Student to Learn (3rd ed.). New York: Routletge.

4. Cahyani, A., Listiana, I. D., \& Larasati, S. P. D. (2020). Motivasi Belajar Siswa SMA pada Pembelajaran Daring di Masa Pandemi Covid-19. IQ (Ilmu Al-Qur'an): Jurnal Pendidikan Islam, 3(01), 123-140. https://doi.org/10.37542/iq.v3i01.57

5. Cynthia, L. C., Martono, T., \& Indriayu, M. (2015). Pengaruh Fasilitas Belajar dan Motivasi Belajar terhadap Prestasi Belajar Mata Pelajaran Ekonomi Siswa Kelas XII IS di SMA Negeri 5 Surakarta Tahun Ajaran 2015/2016. BISE: Jurnal Pendidikan Bisnis Dan Ekonomi, 1(2). https://doi.org/https://doi.org/10.20961/bise. v1i2.17966

6. Emda, \& Amna. (2018). Kedudukan motivasi belajar siswa dalam pembelajaran. Lantanida Journal, 5(2), 172-182.

7. Jannah, S. N., \& Sontani, U. T. (2018). Sarana Dan Prasarana Pembelajaran Sebagai
Faktor Determinan Terhadap Motivasi Belajar Siswa. Jurnal Pendidikan Manajemen Perkantoran, 3(1), 210. https://doi.org/10.17509/jpm.v3i1.9457

8. Kasmaienezhadfard, S., Talebloo, B., Roustae, R., \& Pourrajab, M. (2015). Students' Learning Through Teaching Creativity: Teachers' Perception. Journal of Educational, Health and Community Psychology, 4(1).

9. Kemendikbud. (2020). Surat Edaran Menteri Pendidikan dan Kebudayaan No 4 Tahun 2020 tentang Pelaksanaan Kebijakan Pendidikan dalam Masa Darurat Penyebaran Covid-19. Jakarta: Kemendikbud.

10. Kettler, T., Lamb, K. N., Willerson, A., \& Mullet, D. R. (2018). Teachers' Perceptions of Creativity in the Classroom. Creativity Research Journal, 30(2), 164-171.

11. Kresna, A., \& Ahyar, J. (2020). Pengaruh Physical Distancing Dan Social Distancing Terhadap Kesehatan Dalam Pendekatan Linguistik. Shyntax Transformation, 1(4).

12. Lagili, I. L., Moonti, U., \& Mahmud, M. Z. (2019). Identifikasi Faktor yang Mempengaruhi Motivasi Belajar Mahasiswa pada Program Studi S1 Pendidikan Ekonomi Angkatan 2015 Fak. Ekonomi Univ. Negeri Gorontalo. Economic Education Journal, 1(1), 15-29.

13. Meyer, D. K., \& Turner, J. (2006). Reconceptualizing Emotion and Motivation to Learn in Classroom Context. Journal of Educational Psychology, 18(4), 377-390. doi:10.1007/s10648-006-9032-1

14. Permatasari, N., Ashari, F. R., \& Ismail, N. (2021). Contribution of Perceived Social Support (Peer, Family and Teacher) to Academic Resilience during COVID-19. Golden Ratio of Social Science and Education, 1(1).

15. Purwanto, A., Pramono, R., Asbari, M., Hyun, C. C., Wijayanti, L. M., \& Putri, R. S. (2020). Studi Eksploratif Dampak Pandemi Covid-19 Terhadap Proses Pembelajaran Online di Sekolah Dasar. EduPsyCouns: Journal of Education Psychology and Counseling, 2(1), 1-12.

16. Rosa, N. N. (2020). Hubungan Dukungan Sosial Terhadap Motivasi Belajar Daring Mahasiswa Pada Masa Pandemi Covid-19. TANJAK: Journal of Education and Teaching, 1(2), 147-153. https://doi.org/10.35961/tanjak.v1i2.146 
Endah Ratnawati et.al. Efforts to increase economic learning motivation online through improving learning facilities, teacher creativity and social support during the COVID-19 pandemic.

17. Sarafino, E. P. (1997). Health Psychology: Biopsychosocial Interaction (3rd ed.). New York: John Wiley \& Sons, Inc.

18. Sardiman. (2007). Interaksi dan Motivasi Belajar Mengajar. Jakarta: PT Raja Grafindo Persada.

19. Sari, D. P., \& Rusmin, A. R. (2018). Pengaruh iklim kelas terhadap motivasi belajar peserta didik di SMAN 3 Tanjung Raja. Jurnal PROFIT Kajian Ekonomi Dan Ilmu Ekonomi, 5(1), 80-88.

20. Slameto. (2010). Belajar dan Faktor-faktor yang Mempengaruhinya. Jakarta: Rineka Cipta.

21. Smet, B. (1994). Psikologi Kesehatan (B. Wismanto (ed.)). Jakarta: PT Grasindo.

22. Sugiyono. (2011). Metode Penelitian Pendidikan (Pendekatan Kuantitatif, Kualitatif dan R \& D). Bandung: Alfabeta.

23. Sukiyasa, K., \& Sukoco, S. (2013). Pengaruh Media Animasi terhadap Hasil Belajar dan Motivasi Belajar Siswa Materi Sistem Kelistrikan Otomotif. Jurnal Pendidikan Vokasi, 3(1).

24. Talajan, G. (2012). Menumbuhkan Kreativitas dan Prestasi Guru. Yogjakarta: Laksbang Pressindo.
25. Tan, C. (2020). The Impact of COVID-19 on Student Motivation, Community of Inquiry and Learning Performance. Asian Education and Development Studies, 10(2). https://doi.org/10.1108/AEDS-05-20200084

26. Uno, H. (2011). Teori Motivasi dan Pengukurannya. Jakarta: PT Bumi Aksara.

27. Zaharah, Kirilova, G. I., \& Windarti, A. (2020). Impact of Corona Virus OutbreakTowards Teaching and Learning Activities in Indonesia. SALAM Jurnal Sosial Dan Budaya Syar'i, 07(03), 269-282. https://doi.org/10.15408/sjsbs.v7i3.15104

How to cite this article: Endah Ratnawati, Subagyo, Sugiono. Efforts to increase economic learning motivation online through improving learning facilities, teacher creativity and social support during the COVID-19 pandemic. International Journal of Research and Review. 2022; 9(2): 361-367. DOI: https://doi.org/ 10.52403/ijrr.20220247 